\title{
How the ARCH Project has Contributed to the Development of the ASEAN Regional Collaboration Mechanism on Disaster Health Management
}

Phumin Silapunt, MD; ${ }^{1,14}$ Ferdinal Fernando, MD, MDM; ${ }^{2}$ Jim Catampongan, MSc; ${ }^{2}$ Sansana Limpaporn, MABIT; ${ }^{3}$ Kittima Yuddhasaraprasiddhi, BA ; ${ }^{3}$ Dangfun Promkhum, MPolSc; ${ }^{3}$ Parinya Tianwibool, MD; ${ }^{4,14}$ Phatsawan Sairai, RN, MBA; ${ }^{5,14}$ Hathairat Rungsansarit, RN, MPH; ${ }^{6,14}$ Prasit Wuthisuthimethawee, $\mathrm{MD} ;^{7,14}$ Kanin Keeratipongpaiboon, MD; ${ }^{8,14}$ Nopmanee Tantivesruangdet, MD; Kanungnij Chantaratin, RN, MNS; ${ }^{10,14}$ Gawin Tiyawat, MD; ${ }^{11,14}$ Yosuke Takada, RN, PHN, $\mathrm{PhD} ;^{12,15}$ (1) Taro Kita, BHSc; ${ }^{16,17}$ (1) Soichiro Kai, MD; ${ }^{13,15}$ Shuichi Ikeda, MSc ${ }^{16,17}$ (1)

1. Chulabhorn Hospital, Thailand

2. ASEAN Secretariat

3. National Institute for Emergency Medicine, Thailand

4. Department of Emergency Medicine, Faculty of Medicine, Chiang Mai University, Thailand

5. Maharaj Nakorn Chiang Mai Hospital, Faculty of Medicine, Chiang Mai University, Thailand

6. Patong Hospital, Thailand

7. Department of Emergency Medicine, Faculty of Medicine, Prince of Songkla University, Thailand

8. Bangchak Hospital, Samutprakan, Thailand

9. Department of Emergency Medicine, Rajavithi Hospital, Bangkok, Thailand

10. Relief and Community Health Bureau, the Thai Red Cross Society, Thailand

11. Faculty of Medicine, Navamindradhiraj University, Thailand

12. Japanese Red Cross Hiroshima College of Nursing, Japan

13. Hyogo Emergency Medical Center, Japan

14. Thai Task Force for ARCH Project

15. Japan Advisory Committee for ARCH Project

16. Japan International Cooperation Agency (IICA)

17. JICA Expert Team for Project for Strengthening the ASEAN Regional Capacity on Disaster Health Management (ARCH Project)

Correspondence:

Shuichi Ikeda, Chief Advisor, ARCH Project Japan International Cooperation Agency (JICA),

(JICA Thailand office) 31st floor,

Exchange Tower

388 Sukhumvit Road, Klongtoey Bangkok
10110, Thailand

E-mail: sikeda3620@outlook.jp

Conflicts of interest/financial support: The $\mathrm{ARCH}$ Project was funded by JICA as part of the Official Development Assistance of the government of Japan in collaboration with NIEM/ MOPH Thailand as counterpart agencies. This publication was totally funded by JICA as a part of the ARCH Project. Shuichi Ikeda and Taro Kita are members of the expert team dispatched by JICA. Authors do not have any conflict of interest to declare.

Keywords: ARCH Project; ASEAN Collective Measures (ACM) on Disaster Health Management; Health Needs Assessment (HNA); Regional Coordination Committee on Disaster Health Management (RCC-DHM); Standard Operating Procedure (SOP) for the Coordination of International Emergency Medical Teams (EMTs) in ASEAN

\section{Abbreviations:}

AADMER: ASEAN Agreement on Disaster

Management and Emergency Response

AAR: After Action Review

ACDM: ASEAN Committee on Disaster

Management

ACM: ASEAN Collective Measures

AHA Centre: ASEAN Coordinating Centre for

Humanitarian Assistance on disaster

management

AHC2: ASEAN Health Cluster 2

AHMM: ASEAN Health Ministers Meeting

AIDHM: ASEAN Institute on DHM

ALD: ASEAN Leaders' Declaration

AMS: ASEAN Member States

APHDA: ASEAN Post-2015 Health

Development Agenda

ARCH Project: Project for Strengthening the

ASEAN Regional Capacity on Disaster Health

Management
ARDEX: ASEAN Regional Disaster Emergency Response Simulation Exercise

ASEAN: Association of Southeast Asian Nations BDHM: Basic Disaster Health Management

COVID-19: Coronavirus Disease 2019

DELSA: Disaster Emergency Logistic System for ASEAN

DHM: Disaster Health Management

EMT: Emergency Medical Team

EMTCC: Emergency Medical Team Coordination Cell

HNA: Health Needs Assessment

IASC: Inter-Agency Standing Committee

I-EMT: International Emergency Medical Team

JTF-HADR: Joint Task Force to Promote Synergy

with Other Relevant ASEAN Bodies on

Humanitarian Assistance and Disaster Relief

MIRA: Multi-Cluster Initial Rapid Assessment

MRA: ASEAN Mutual Recognition Arrangement

MRED: Medical Record for Emergency and

Disaster

OAOR: One ASEAN One Response

PHEOC: Public Health Emergency Operations

Center

POA: Plan of Action

PWG: Project Working Group

RCC: Regional Coordination Committee

RCCDHM: Regional Coordination Committee on

Disaster Health Management

RCD: Regional Collaboration Drill

SASOP: Standard Operating Procedure for

Regional Standby Arrangements and

Coordination of Joint Disaster Relief and

Emergency Response Operations

SOD: Sudden Onset Disasters

SOMHD: Senior Officials Meeting on Health

Development

SOP: Standard Operating Procedure

SWG: Sub Working Group

TTX: Table-top exercise 
WG-PRR: Working Group on Preparedness, Response and Recovery WHO: World Health Organization

Received: November 21, 2021

Accepted: December 4, 2021

\section{doi:10.1017/S1049023X2200005X}

(C) The Author(s), 2022. Published by Cambridge University Press on behalf of World Association for Disaster and Emergency Medicine. This is an Open Access article, distributed under the terms of the Creative Commons

Attribution-NonCommercial-ShareAlike licence (https://creativecommons.org/ licenses/by-nc-sa/4.0/), which permits non-commercial re-use, distribution, and reproduction in any medium, provided the same Creative Commons licence is included and the original work is properly cited. The written permission of Cambridge University Press must be obtained for commercial re-use.

\begin{abstract}
Objective: This paper aims to clarify how the Project for Strengthening the ASEAN Regional Capacity on Disaster Health Management (ARCH Project) strengthened regional collaboration mechanisms on disaster health management (DHM) in ASEAN. Methods: The political process and the relevant documents of the ARCH Project were reviewed.
\end{abstract}

Results: The ARCH Project established the Regional Coordination Committee as a coordination platform for providing strategic direction to the project and strengthening the regional coordination of DHM. Also, the Project Working Groups and Sub-Working Groups were set up as implementation bodies for the project activities with representatives of ASEAN Member States (AMS). With support from DHM experts of Japan and Thailand, a series of discussions were conducted for the development of a Standard Operating Procedure (SOP) for the Coordination of International Emergency Medical Teams (IEMTs), regional tools, and collective measures supporting AMS to overcome challenges, and thereby meeting the minimum requirements set by the WHO EMT Initiative. The progress and outputs of the ARCH Project are subsequently elevated to the ASEAN Health Sector for endorsement, the updates are further shared to the Joint Task Force to Promote Synergy with Other Relevant ASEAN Bodies on Humanitarian Assistance and Disaster Relief (JTF-HADR) for the implementation of the ASEAN Declaration on One ASEAN One Response. The initiation of the ARCH Project in July 2016 has resulted in the development of the ASEAN regional collaboration framework, including the establishment of the Regional Coordination Committee on Disaster Health Management (RCCDHM), the SOP for ASEAN I-EMT coordination, and regional tools, such as forms for Medical Record for Emergency and Disaster and Health Needs Assessment. Moreover, further discussions on ASEAN Collective Measures that aim to support AMS to meet the WHO EMT minimum standards and strengthening I-EMT coordination capacity were also conducted. As adopted by the ASEAN Health Ministers Meeting (AHMM) in 2019, the RCCDHM was established as one of the mechanisms to operationalize the Plan of Action to implement the ASEAN Leaders' Declaration on DHM.

Conclusion: The contribution of the ARCH Project to strengthen the ASEAN regional capacity in DHM has enhanced the regional coordination platform, with a formalization of RCCDHM as ASEAN's official regional mechanism, and of the on-going integration process of the SOP for EMT coordination into the ASEAN SASOP.

Silapunt P, Fernando F, Catampongan J, Limpaporn S, Yuddhasaraprasiddhi K, Promkhum D, Tianwibool P, Sairai P, Rungsansarit H, Wuthisuthimethawee P, Keeratipongpaiboon K, Tantivesruangdet N, Chantaratin K, Tiyawat G, Takada Y, Kita T, Kai S, Ikeda S. How the ARCH Project has Contributed to the Development of the ASEAN Regional Collaboration Mechanism on Disaster Health Management. Prehosp Disaster Med. 2022;37(Suppl. 1): s16-s29.

\section{Impact and Contribution to ASEAN Regional Policy and Strategy (ALD on DHM, and POA, APHDA)}

The ASEAN Health Sector places high priority on enhancing regional and national capacities in health risk and emergency management, strengthening regional health security, and enhancing health systems in the region, among others based on its ASEAN Health Development Agenda. 1,2 The above strategic areas are accorded priority considering the significant burden brought about by disasters, public health emergencies, and related crises to the health and livelihoods of populations, and to the resilience of health systems in the region.

The ASEAN Post-2015 Health Development Agenda (APHDA) was adopted by the ASEAN Health Ministers Meeting in 2014 and articulates the ASEAN Health Sector's contribution to the ASEAN Socio-Cultural Community Blueprint 2025. The APHDA also identifies disaster health management (DHM) as one of the 20 Health Priorities, and is under the purview of ASEAN Health Cluster 2 on Responding to All Hazards and Emerging Threats. ${ }^{2}$ As outlined in this Cluster's Work Programme, DHM currently prioritizes advocacy and strengthening of regional cooperation and national capacity on preparedness and response to the health aspects of disasters, public health emergencies, and related crises.

The priority accorded to DHM was further galvanized through the adoption of the ASEAN Leaders' Declaration (ALD) on DHM at the $31^{\text {st }}$ ASEAN Summit (2017) and the Plan of Action (POA) to implement the ALD at the $14^{\text {th }}$ ASEAN Health Ministers Meeting (2019). ${ }^{3}$ The ALD and POA outline strategic priorities related to development of mechanisms and procedures for effective regional health response, including allocation and mobilization of assets and capacities; strengthening of all-hazards health emergency and disaster risk management programs; and institutionalization of DHM. Further, it included ensuring availability of adequate financing, safe resilient hospitals and health facilities, innovation through research and development and multisectoral cooperation, and also promotion of public and private investments in disaster risk reduction. These also sum up the ASEAN Health Sector's contributions to the ASEAN Declaration on One ASEAN One Response (2016), which aspires for increased speed, scale, and solidarity of ASEAN's response, and further to the ASEAN Agreement on Disaster Management and Emergency Response (AADMER). ${ }^{1,4}$

The Project for Strengthening the ASEAN Regional Capacity on Disaster Health Management (ARCH Project) has played a critical role in the realization of ASEAN's vision and strategic program and project activities on DHM, and particularly on the medical aspects of disaster health response. ${ }^{5}$ The ARCH Project has led 
the translation of policies and strategies into regional programs and specific initiatives, and tangible capacities, as elaborated in succeeding sections of this article. It has also contributed to the robustness and scientific rigor of the aforementioned POA through the active engagement of relevant technical contact points and existing platforms of health.

The progress and outputs of the ARCH Project have become integral part of the ASEAN Health Sector mechanisms after concurrence and endorsement by the ASEAN Health Cluster 2 (AHC 2) and the Senior Officials Meeting on Health Development (SOMHD), following its Governance and Implementation Mechanism. Project updates are further shared to the Joint Task Force to Promote Synergy with Other Relevant ASEAN Bodies on Humanitarian Assistance and Disaster Relief (JTF-HADR), a multi-sectoral platform that facilitates the implementation of the ASEAN Declaration on One ASEAN One Response: Responding to Disasters as One in the Region and Outside the Region.

The ARCH Project, through Lead Country Thailand and Contact Points from ASEAN Member States (AMS), has also contributed to the on-going Mid-Term Review of APHDA and Work Programmes 2016-2020 of the ASEAN Health Clusters. As DHM continues to be a priority of the ASEAN Health Sector for 2021-2025 and as the ARCH Project also embarks on Phase 2 (2022-2026), it will continue to play a significant role in strengthening regional capacities in disasters, as well as in public health emergency preparedness building on ASEAN's experience from the coronavirus disease 2019 (COVID-19) pandemic.

\section{Development of ASEAN Regional Collaboration Framework and Tools A. Regional Coordination Committee on Disaster Health Management (RCC-DHM)}

The ARCH Project was started in 2016 when ASEAN through the ASEAN Health Sector defined DHM as one of 20 Health Priorities in APHDA, and subsequently, it became the major project in development of ASEAN DHM. ${ }^{2,5}$ The ARCH Project is composed of two Project Working Groups (PWGs), supervised by a Regional Coordination Committee (RCC)$\mathrm{ARCH}$, where there is a coordination platform for AMS in DHM.

The RCC-ARCH in coordination with the ARCH Project team drafted and drove ALD on DHM and its POA, the former was officially adopted by the ASEAN Summit in Manila, the Philippines in 2017, and the latter was subsequently adopted by the ASEAN Health Ministers' Meeting (AHMM) in 2019, respectively. ${ }^{3,6}$ As a result, the Regional Coordination Committee on Disaster Health Management (RCCDHM) was established in order to coordinate and drive the implementation of the POA to achieve its 21 targets, which include the 14 regional and seven national targets. ${ }^{6}$ As the official coordination mechanism of the ASEAN Health Sector on DHM, the RCCDHM has been created to provide strategic directions to the $\mathrm{ARCH}$ Project and resulted in the dissolution of the $\mathrm{RCC}-\mathrm{ARCH}$.

RCCDHM was established in 2020, and is chaired by the incumbent Chair of the $\mathrm{AHC} 2$, and consists of two representatives from each AMS that includes a representative from the ASEAN Coordinating Centre for Humanitarian Assistance on disaster management (AHA Centre) and the ASEAN Secretariat. ${ }^{7}$ The committee is responsible for:
- Facilitating the development of regional collaboration on DHM.

- Collaborating with relevant ASEAN sectoral bodies both in the health and non-health sectors and other international organizations.

- Developing standard operating procedures (SOPs) and other collaboration tools.

- Facilitating and providing policy guidance in development of regional collaboration drills (RCDs) on DHM in AMS.

- Facilitating and supporting the academic activities related to DHM.

- Facilitating the establishment of a regional disaster health training center.

Recently, the ARCH Project and the RCCDHM, together, are pushing the establishment of an ASEAN Academic Network on DHM and the ASEAN Institute on Disaster Health Management (AIDHM) to be two key mechanisms in AMS capacity building. The ARCH Project is, therefore, a project that drives ASEAN mechanisms in DHM to be consistent and sustainable and under supportive policies by ASEAN Summit and AHMM.

\section{B. Standard Operating Procedure (SOP) for AMS International Emergency Medical Team (I-EMT)}

Standard Operating Procedure for Coordination of Emergency Medical Teams in ASEAN (ASEAN SOP for I-EMT Coordination) was drafted through several processes: (1) country survey on DHM; (2) exercises and drills with after action review (AAR) inputs; (3) literature review; and (4) AMS representative meeting.

A comprehensive literature review was conducted prior to the commencement of the ARCH Project and during the development of ASEAN SOP for I-EMT Coordination. In the country survey report, ASEAN SOP for Regional Standby Arrangements and Coordination of Joint Disaster Relief and Emergency Response Operations (ASEAN SASOP), WHO Emergency Medical Teams Coordination Cell (EMTCC), and other relevant documents were reviewed and analyzed by an expert team in order to draft the SOP. ${ }^{8-10}$

The country surveys in AMS were conducted prior to the commencement of the ARCH Project to be baseline information of current DHM capacity in all ASEAN countries. ${ }^{10}$ The group of experts (emergency medicine and disaster management), researchers, and project's representative reviewed documents relevant to DHM of each country prior to country visits and inspected activities. National DHM organizations in each AMS were visited and responsible persons for DHM were interviewed. All collected country information was recorded in the standard platform and a final report was created that acted as a crucial input for the preparation of $\mathrm{ARCH}$ Project. ${ }^{10}$

The ASEAN representative (PWG 1) meeting is the most important activity in the development of ASEAN SOP for EMT. Academic and management representatives related to DHM from all AMS shared and discussed the drafted SOP before making conclusions on the SOP to be tested in the next drill/exercise activity.

The PWG 1 also discussed developing and organizing a series of RCDs (including table-top and field simulation) with the following objectives: Start up RCD (Thailand) to gather baseline 
information of I-EMT's personnel and team capacities. The three RCDs proposed were: 1st: Thailand; 2nd: Viet Nam; and 3rd: Philippines. They were aimed to test drafted SOP for I-EMT Coordination and identify gaps in EMT operation.

The draft ASEAN SOP for I-EMT Coordination was reviewed and endorsed by the RCC-ARCH and subsequently by AHC2. The draft SOP was later transmitted to the ASEAN Committee on Disaster Management (ACDM) for review and guidance on its integration with ASEAN SASOP. Following the review by the ACDM Working Group on Preparedness, Response, and Recovery (WG-PRR), a recommendation was given for the draft SOP to undergo further reviews and testing via a Table-Top Exercise (TTX) and field testing via ASEAN Regional Disaster Emergency Response Simulation Exercise (ARDEX). The TTX was organized by the AHA Centre and $\mathrm{ARCH}$ Project with the involvement of disaster management and health representatives of AMS.

The integration of the ASEAN SOP for I-EMT Coordination into the ASEAN SASOP is expected to be discussed and concluded during 2021, in view of the uncertainty of the conduct of ARDEX due to the COVID-19 pandemic.

\section{Development of Regional Forms for AMS I-EMT}

1. Medical Record for Emergency and Disaster-Information management is one of the cornerstone procedures in disaster relief operations, especially for I-EMTs and public health personnel. The information can be used in operational analysis and strategic planning. The standard platform and reports are the major concern and challenges in information management during disaster relief activity. Standardized Medical Record for Emergency and Disaster (MRED) and health need assessment (HNA) forms did not exist and needed to be created and implemented.

A variety of methods were applied in the development of the MRED and HNA forms. The literature on medical records in disaster relief operation, standard disaster medical record of Japan, common platforms of the record forms, and necessary information for report and management such as tally sheets and daily reports of the WHO EMT Minimum Data Set (MDS) were reviewed. The drafted MRED form, which is compatible with the WHO EMT MDS daily reporting, was presented in PWG 1 for discussion, comment, and making conclusions on the platform and information in the form. The PWG 1 tested the MRED and HNA forms through the table-top exercises in the AMS training programs for practical and management perspectives of I-EMTs.

The MRED and HNA forms (Figure 1, Figure 2, and Figure 3) were successfully implemented to become standard forms for AMS I-EMT, and are now in the process of integration into the ASEAN SASOP as the annex document of the SOP for I-EMT Coordination. To the best of the authors' knowledge, this is the first case of standardization of EMT MRED across the regional countries.

\section{HNA Form-ARCH Project developed an integrated HNA} form for AMS I-EMT.

The ARCH Project conducted a start-up RCD in Thailand in 2016, a field simulation exercise for EMTs in ASEAN. The assessment scenario was an important part of the simulations. This evaluation occurred when the Public Health-Emergency Operation Center (PHEOC) had asked the EMTs to assess the situation in the unassessed area. All drill participants conducted observations and interviews, but they realized the need for standardized assessment forms for regional collaboration.

The PWG 1, therefore, started to develop an integrated HNA form in the ASEAN region. PWG 1 consisted of the Japanese expert team, Thai task force, Japanese Advisory Committee (JAC), and two representatives from each AMS. The expert team prepared a draft of the HNA form and then repeatedly organized the PWG 1 meetings to build consensus. The drafted form approved by the PWG 1 was tested repeatedly in a series of RCDs and reviewed for its efficacy and usability and was further modified for improvement.

The purpose of HNA form development is to assist the rapid health assessments conducted by the EMTs, even in environments where lifelines have been interrupted, in a portable and easy to manage format. The PWG 1 created two forms, the HNA form and the summary form, to operate the system with paper and pen, assuming it will be used at the disaster site without electricity. The number of pages was reduced as much as possible. So, it was completed on three A4-size sheets of paper, for a total of six pages (Figure 2 and Figure 3). The forms contained more checkboxes and had less text to fill in, reducing the burden of writing the form. Moreover, it was simplifying the data structure, making it easier to tabulate.

The assessment form (Figure 2) consists of six primary items: (1) informant information; (2) site information with access and security; (3) shelter information; (4) overall situation of the site/shelter including the total population; (5) public health, such as water, sanitation, and hygiene (WASH), food security, and nutrition; and (6) health facility damage. The total number of the secondary items are 83 in the assessment form. The summary form (Figure 2) consists of four primary items: (1) informant information; (2) site/shelter information; (3) critical areas for support; and (4) situation of the site. The total number of the secondary items are 22 in the summary form. Initially, the form was eight pages to reflect each country's opinions. However, after testing in the three RCDs, PWG 1 revised the form according to the opinions of the drill participants on areas for improvement.

In disaster situations, it is often difficult to obtain detailed and accurate information. Therefore, for ingenious operation of this tool, PWG 1 members agreed that this HNA form would be used as an interview guide. This means that it will not be a mandate to fill out all the items/questions, and only relevant available information in the site/shelter can be collected. Instead, the summary form will be used as the final report.

In conjunction with the HNA form development, the PWG 1 has created a guidance note for practical use. It guides the PHEOC to grasp and coordinate the EMT locations in order to avoid duplication. There are two assessment methods for EMT to fill in the form: direct observation and key informant interviews. Each EMT can use both methods to the full extent to assess the situation.

Globally, the Inter-Agency Standing Committee (IASC) has proposed the Multi-Cluster Initial Rapid Assessment (MIRA) as a unified assessment tool in 2012. ${ }^{11}$ This is underpinned by an analytical framework that guides the systematic collection, organization, and analysis of secondary and primary data. The United Nations (UN) and the international NGOs are using it for humanitarian assistance. However, there was no standardized assessment form available.

This HNA form is one of the milestones for strengthening regional capacity in DHM that all ASEAN countries have agreed to use for conducting rapid assessments for health. Using the same 


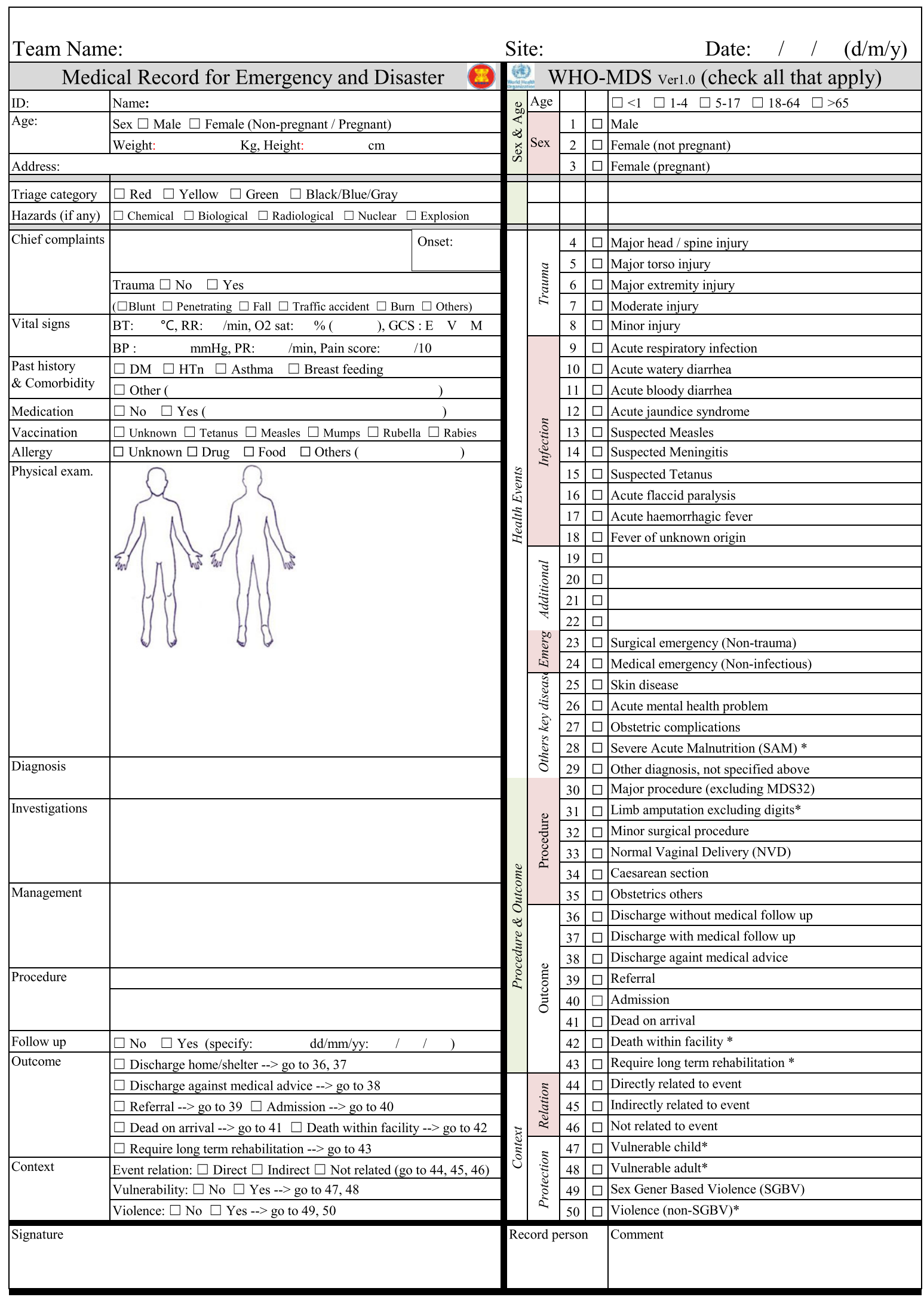

Silapunt $\odot 2022$ Prehospital and Disaster Medicine

Figure 1. Medical Record for Emergency and Disaster (MRED) Form (continued).

Note: This form is available in an Excel sheet. https://docs.google.com/spreadsheets/d/1yvVzN-N-eoUjXTWfZ_YK4OEC $\mathrm{W} 4 \circ \mathrm{CuFp} 0 /$ edit?usp=sharing\&ouid $=103468978621981742764 \& \mathrm{rtpof}=$ true\&sd=true. 


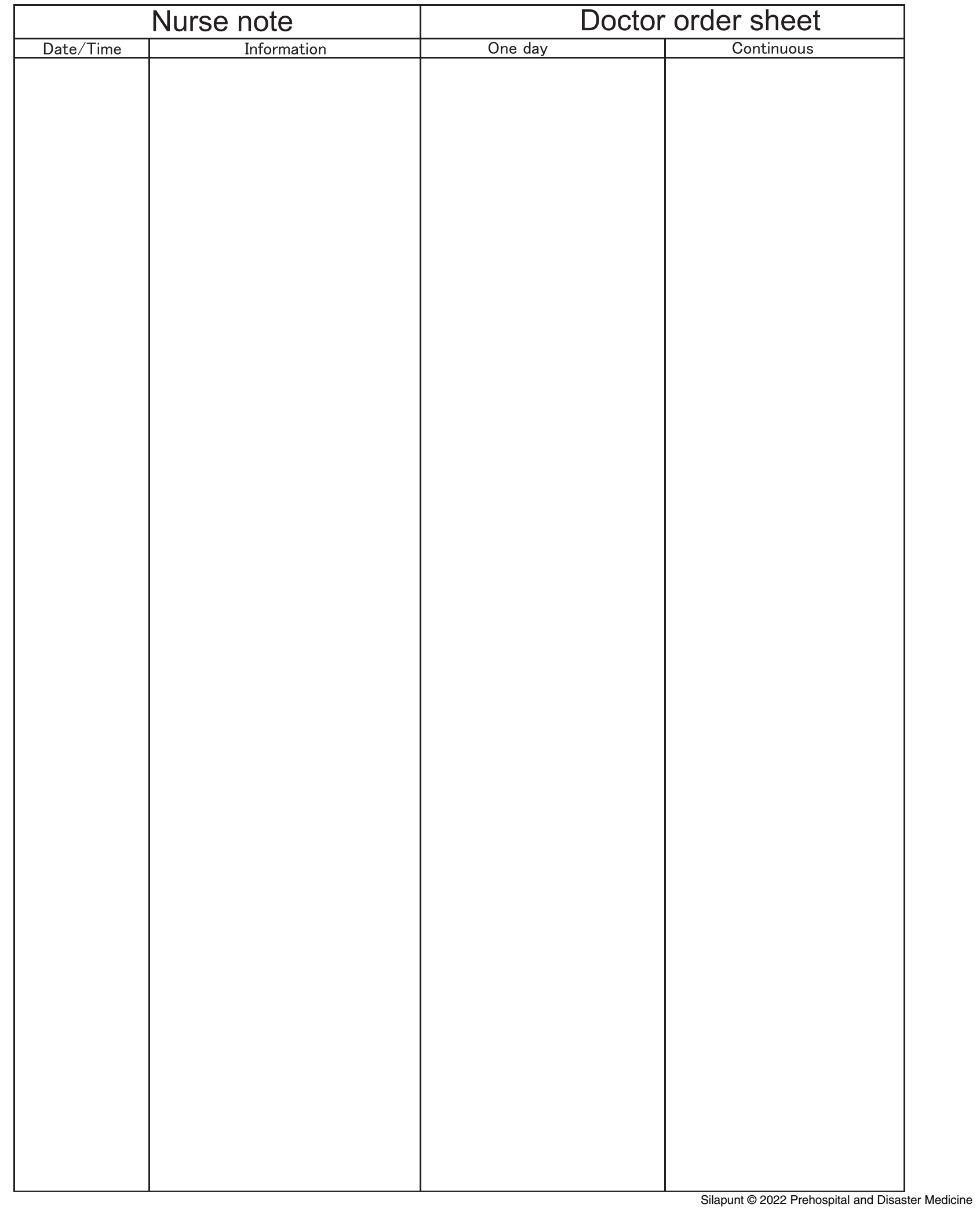

Figure 1. (continued). Medical Record for Emergency and Disaster (MRED) Form. 
ARCH Project HNA Form (Version 2-4)

\section{Date(DD/MM/YYYY)}

\section{Health Needs Assessment Form by EMT}

$>$ It is NOT mandatory to fill out all the questions; only relevant and available information in the site or shelter(s) can be collected.

$>$ After the assessment, please fill out the HNA Summary Report and submit it to the concerned authorities, EMTCC/PHEOC/MOH, etc.

\begin{tabular}{|l|l|l|l|}
\hline \multicolumn{2}{|l|}{ EMT Information } \\
\hline Country / Organization & \multicolumn{2}{|l|}{} \\
\hline Contact Persons (Names) & \multicolumn{2}{|l|}{} \\
\hline Phone No. & & e-mail & \\
\hline
\end{tabular}

* This HNA Form is for: Please check either "village/town etc." or "shelter" below.

\begin{tabular}{|l|l|ll|}
\hline$\square$ village/town etc. & $\rightarrow$ Fill out & $\square$ shelter & Fill out \\
& A: Site Information & A: Site Information \\
\hline
\end{tabular}

\section{A. Site Information}

\begin{tabular}{|c|l|l|l|l|l|}
\hline A. Site Information & D & Village & \\
\hline A & Province & & E & City/Town & \\
\hline B & District & F & Other & \\
\hline C & Sub-district & & & \\
\hline
\end{tabular}

\section{Access and Security}

\begin{tabular}{|c|c|c|c|}
\hline G & Road access & $\square$ Yes $\square$ No & \\
\hline \multirow{2}{*}{$\mathrm{H}$} & \multirow{2}{*}{$\begin{array}{l}\text { Special } \\
\text { arrangement } \\
\text { required }\end{array}$} & $\begin{array}{l}\text { Transportation (e.g., 4WD, boat) } \\
\square \text { Yes }\end{array}$ & $\square$ No \\
\hline & & $\begin{array}{l}\text { Communication tool (e.g., satellite phone) } \\
\square \text { Yes }\end{array}$ & $\square$ No \\
\hline I & $\begin{array}{l}\text { Any other } \\
\text { security } \\
\text { concerns }\end{array}$ & $\square$ Yes & $\square$ No \\
\hline
\end{tabular}

\section{Remarks/ Notes:}

\section{B: Shelter Information}

\begin{tabular}{|c|l|l|c|l|}
\hline A & Shelter Name: & B & $\begin{array}{l}\text { Location of Shelter: } \\
\text { (GPS Coordinates) }\end{array}$ \\
\hline C & Type of Shelter & $\begin{array}{l}\square \text { Public } \square \text { Pre-existing building } \\
\square \text { Other (specify) }\end{array}$ \\
\hline D & Capacity & $\square$ Temporary structure \\
\hline
\end{tabular}

Figure 2. Health Needs Assessment (HNA) Form by EMT (continued).

Note: This form is available in a Word document. https://docs.google.com/document/d/14GT9hjAyULjlyWK16mw8x04ak U9heMpG/edit?usp=sharing\&ouid=103468978621981742764\&urtpof=true\&sd=true. 


\section{Overall Situation of the Site or Shelter}

\begin{tabular}{|c|c|c|}
\hline 1 & \multicolumn{2}{|l|}{ Disaster Situation on Population and Health Needs } \\
\hline $1-1$ & Estimated number of total population & $(\#)$ \\
\hline $1-2$ & Estimated number of death & $(\#)$ \\
\hline $1-3$ & Main causes of death by the disaster & . \\
\hline $1-4$ & Estimated number of injured/ill & $\begin{array}{l}\square \text { infant \& children (Under } 5 \text { years) } \\
\square \text { children \& adolescent (aged } 6-19) \\
\square \text { adult (older than } 19 \text { years of age) }\end{array}$ \\
\hline $1-5$ & Total number of pregnant women & $(\#)$ \\
\hline $1-6$ & Number of patients suffering from chronic diseases & $(\#)$ \\
\hline $1-7$ & Any unusual increased illness or rumors of outbreaks & $\begin{array}{l}\square \text { Yes (specify) } \\
\square \text { No }\end{array}$ \\
\hline $1-8$ & $\begin{array}{l}\text { Number of people with mental health and psychosocial } \\
\text { problems }\end{array}$ & 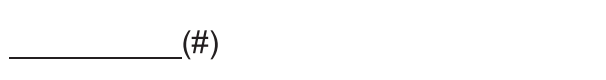 \\
\hline $1-9$ & Main health concerns & $\begin{array}{l}1 . \\
2 . \\
3 .\end{array}$ \\
\hline Rem & s/ Notes: Observation points/Significance/Possible actic & and follow-ups etc. \\
\hline
\end{tabular}

\begin{tabular}{|c|c|c|}
\hline 2 & \multicolumn{2}{|l|}{ Public Health } \\
\hline \multicolumn{3}{|c|}{ Water } \\
\hline $2-1$ & Main sources of water for drinking & $\begin{array}{l}\square \text { piped water } \square \text { tube well } \square \text { spring } \square \text { bottled water } \\
\square \text { other }\end{array}$ \\
\hline $2-2$ & $\begin{array}{l}\text { Main sources of water for basic hygiene } \\
\text { practices (bathing etc.) }\end{array}$ & $\begin{array}{l}\square \text { piped water } \square \text { tube well } \square \text { spring } \square \text { rainwater } \\
\square \text { other }\end{array}$ \\
\hline $2-3$ & Safe water for drinking & $\begin{array}{l}\square \text { Adequate (2.5-3l/person/day) } \quad \square \text { Not Adequate } \\
\text { (last for__day/month) }\end{array}$ \\
\hline $2-4$ & Safe water for basic hygiene practices & $\begin{array}{l}\square \text { Adequate (2-6l/person/day) } \\
\text { (last for__ day/month) } \quad \square \text { Not Adequate }\end{array}$ \\
\hline $2-5$ & Potential risk of water contamination & $\square$ Yes ( \\
\hline \multicolumn{3}{|c|}{ Remarks/ Notes: Observation points/Significance/Possible action and follow-ups etc. } \\
\hline
\end{tabular}

Figure 2. Health Needs Assessment (HNA) Form by EMT (continued). 


\begin{tabular}{|c|c|c|c|c|}
\hline \multicolumn{5}{|c|}{ Sanitation and Hygiene } \\
\hline $2-6$ & \multicolumn{2}{|c|}{ Shortage of functional latrine or toilet (20 persons/toilet) } & $\square$ Yes & $\square$ No \\
\hline $2-7$ & \multicolumn{2}{|l|}{ Problem with garbage/waste } & $\square$ Yes & $\square$ No \\
\hline $2-8$ & \multicolumn{2}{|l|}{ Stagnate water in the area } & $\square$ Yes & $\square$ No \\
\hline $2-9$ & \multicolumn{2}{|l|}{ Vector problem (e.g. mosquitoes, dogs, snakes) } & $\square$ Yes & $\square$ No \\
\hline \multicolumn{5}{|c|}{ Remarks/ Notes: Observation points/Significance/Possible action and follow-ups etc. } \\
\hline \multicolumn{5}{|c|}{ Food Security and Nutrition } \\
\hline $2-10$ & Number of population required food & 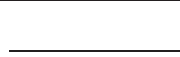 & \multicolumn{2}{|l|}{$(\#)$} \\
\hline $2-11$ & Any food assistance since the event & \multicolumn{2}{|c|}{$\square$ Yes (go to $2-12,13$ ) } & $\square$ No (go to $2-13$ ) \\
\hline $2-12$ & For how long provided food sufficient & \multicolumn{2}{|l|}{$\square$ days } & $\square$ weeks \\
\hline $2-13$ & What kinds of food available or provided & \multicolumn{3}{|c|}{$\begin{array}{l}\square \text { Rice, Wheat, Noodle, etc. (Carbohydrate) } \\
\square \text { Chicken, Other Meat, Fish, Eggs, etc. (Protein) } \\
\square \text { Cooking oil, Other fats, etc. (Fats) } \\
\square \text { Fruits, Vegetables (Vitamin, Fiber) } \\
\square \text { Complementary food } \\
\square \text { Other } \\
\square \text { No food stocks }\end{array}$} \\
\hline \multirow{2}{*}{$2-14$} & \multirow{2}{*}{ Food and Nutrition } & \multicolumn{3}{|c|}{$\begin{array}{l}\square \text { Adequate } \\
>\quad \text { (e.g.) People eating } 3 \text { meals a day. } \\
\text { Babies get enough milk. }\end{array}$} \\
\hline & & \multicolumn{3}{|c|}{$\begin{array}{l}\square \text { Not adequate } \\
\quad \quad \text { (e.g.) People eating smaller meals since the event. } \\
\quad \text { People eating fewer meals a day. } \\
\text { People eating limited varieties of foods. }\end{array}$} \\
\hline $2-15$ & $\begin{array}{l}\text { Obvious signs of undernutrition in children } \\
\text { aged } 6-59 \text { months }\end{array}$ & $\square$ Yes & 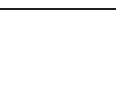 & $\square$ No \\
\hline \multicolumn{5}{|c|}{ Remarks/ Notes: Observation points/Significance/Possible action and follow-ups etc. } \\
\hline
\end{tabular}

Figure 2. Health Needs Assessment (HNA) Form by EMT (continued).

Silapunt $\odot 2022$ Prehospital and Disaster Medicine 


\begin{tabular}{|c|c|c|c|c|c|c|c|c|}
\hline 3 & \multicolumn{8}{|c|}{ Health Facilities and Services } \\
\hline \multicolumn{3}{|c|}{$\begin{array}{l}\text { Type of Facility } \\
\text { *Pls. write the type of facility where } \\
\text { necessary. } \\
\text { (Name of Facility) }\end{array}$} & \multicolumn{2}{|l|}{$\begin{array}{l}\text { Hospital } \\
* \\
(\end{array}$} & \multicolumn{2}{|c|}{$\begin{array}{l}\text { Primary Care Unit (e.g.) } \\
* \\
(\end{array}$} & \multicolumn{2}{|l|}{$\begin{array}{l}\text { Other } \\
* \\
(\end{array}$} \\
\hline \multicolumn{3}{|c|}{ 3-1. Impact on Health Facilities } & \multicolumn{2}{|c|}{$\begin{array}{l}\square \text { Functioning } \\
\square \text { Partially functioning } \\
\square \text { Not functioning }\end{array}$} & \multicolumn{2}{|c|}{$\begin{array}{l}\square \text { Functioning } \\
\square \text { Partially functioning } \\
\square \text { Not functioning }\end{array}$} & \multicolumn{2}{|c|}{$\begin{array}{l}\square \text { Functioning } \\
\square \text { Partially functioning } \\
\square \text { Not functioning }\end{array}$} \\
\hline \multicolumn{3}{|c|}{$\begin{array}{l}3-2 \text {. Is the health facility } \\
\text { accessible? }\end{array}$} & \multicolumn{2}{|c|}{$\begin{array}{l}\square \text { Yes, by what means? } \\
(\square \text { No }\end{array}$} & \multicolumn{2}{|c|}{$\begin{array}{l}\square \text { Yes, by what means? } \\
(\square \text { No } \\
\square\end{array}$} & \multicolumn{2}{|c|}{$\begin{array}{l}\square \text { Yes, by what means? } \\
(\square \text { No }\end{array}$} \\
\hline \multirow{5}{*}{\multicolumn{2}{|c|}{$\begin{array}{l}\text { 3-3. } \\
\text { Availability of }\end{array}$}} & Electricity & $\square$ Yes & $\square$ No & $\square$ Yes & $\square$ No & $\square$ Yes & $\square$ No \\
\hline & & Water & $\square$ Yes & $\square$ No & $\square$ Yes & $\square$ No & $\square$ Yes & $\square$ No \\
\hline & & Medical Gas & $\square$ Yes & $\square$ No & $\square$ Yes & $\square$ No & $\square$ Yes & $\square$ No \\
\hline & & Communication & $\square$ Yes & $\square$ No & $\square$ Yes & $\square$ No & $\square$ Yes & $\square$ No \\
\hline & & Transportation & $\square$ Yes & $\square$ No & $\square$ Yes & $\square$ No & $\square$ Yes & $\square$ No \\
\hline \multirow{7}{*}{\multicolumn{2}{|c|}{$\begin{array}{l}\text { 3-4. } \\
\text { Availability of }\end{array}$}} & Essential Drugs & $\begin{array}{l}\square \text { Yes } \\
\square \text { No ( }\end{array}$ & & $\begin{array}{l}\square \text { Yes } \\
\square \text { No ( }\end{array}$ & ) & $\begin{array}{l}\square \text { Yes } \\
\square \text { No ( }\end{array}$ & \\
\hline & & Vaccines & $\begin{array}{l}\square \text { Yes } \\
\square \text { No ( }\end{array}$ & & $\begin{array}{l}\square \text { Yes } \\
\square \text { No ( }\end{array}$ & ) & $\begin{array}{l}\square \text { Yes } \\
\square \text { No ( }\end{array}$ & \\
\hline & & Medical & $\square$ Yes & & $\square$ Yes & & $\square$ Yes & \\
\hline & & Equipment & $\square$ No ( & & $\square$ No ( & ) & $\square$ No ( & ) \\
\hline & & Medical & $\square$ Yes & & $\square$ Yes & & $\square$ Yes & \\
\hline & & Supplies & $\square$ No ( & & $\square$ No ( & ) & $\square$ No ( & ) \\
\hline & & $\begin{array}{l}\text { Other } \\
(\end{array}$ & $\begin{array}{l}\square \text { Yes } \\
\square \text { No ( }\end{array}$ & & $\begin{array}{l}\square \text { Yes } \\
\square \text { No ( }\end{array}$ & )) & $\begin{array}{l}\square \text { Yes } \\
\square \text { No ( }\end{array}$ & )) \\
\hline \multirow{13}{*}{\multicolumn{2}{|c|}{$\begin{array}{l}\text { 3-5. Health } \\
\text { Staff Working }\end{array}$}} & \multirow{2}{*}{ Doctor } & & persons (\#) & & persons (\#) & & persons (\#) \\
\hline & & & $\square<50 \%$ & $\square>50 \%$ & $\square<50 \%$ & $\square>50 \%$ & $\square<50 \%$ & $\square>50 \%$ \\
\hline & & \multirow{2}{*}{ Nurse } & & persons (\#) & & persons (\#) & & persons (\#) \\
\hline & & & $\square<50 \%$ & $\square>50 \%$ & $\square<50 \%$ & $\square>50 \%$ & $\square<50 \%$ & $\square>50 \%$ \\
\hline & & \multirow{2}{*}{ Pharmacist } & & persons (\#) & & persons (\#) & & persons (\#) \\
\hline & & & $\square<50 \%$ & $\square>50 \%$ & $\square<50 \%$ & $\square>50 \%$ & $\square<50 \%$ & $\square>50 \%$ \\
\hline & & \multirow{2}{*}{ Lab technician } & & persons (\#) & & persons (\#) & & persons (\#) \\
\hline & & & $\square<50 \%$ & $\square>50 \%$ & $\square<50 \%$ & $\square>50 \%$ & $\square<50 \%$ & $\square>50 \%$ \\
\hline & & \multirow{2}{*}{ Midwife } & 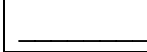 & persons (\#) & & persons (\#) & & persons (\#) \\
\hline & & & $\square<50 \%$ & $\square>50 \%$ & $\square<50 \%$ & $\square>50 \%$ & $\square<50 \%$ & $\square>50 \%$ \\
\hline & & \multirow{2}{*}{$\begin{array}{l}\text { Community } \\
\text { Health Worker }\end{array}$} & & persons (\#) & & persons (\#) & & persons (\#) \\
\hline & & & $\square<50 \%$ & $\square>50 \%$ & $\square<50 \%$ & $\square>50 \%$ & $\square<50 \%$ & $\square>50 \%$ \\
\hline & & \multicolumn{7}{|l|}{ Remarks/Notes } \\
\hline
\end{tabular}

Figure 2. (continued). Health Needs Assessment (HNA) Form by EMT. 


\section{Health Needs Assessment (HNA) Summary Report}

1. EMT Information

\begin{tabular}{|l|l|l|}
\hline \multirow{2}{*}{ EMT Information } & Country / Organization: & Contact Person: \\
\cline { 2 - 3 } & Contact No: & Email: \\
\hline
\end{tabular}

\section{HNA Site/Shelter Information}

\begin{tabular}{|l|l|l|}
\hline $\begin{array}{l}\text { Date of Assessment } \\
\text { (dd/mm/yy) }\end{array}$ & $\begin{array}{l}\text { Date of Submission } \\
\text { (dd/mm/yy) }\end{array}$ & \\
\hline This HNA was done in: Pls. check the Box below \& write the location of the site or shelter. \\
\hline$\square$ Site $\square$ Shelter & \\
\hline $\begin{array}{l}\text { Security concerns or } \\
\text { other information if any }\end{array}$ & \\
\hline
\end{tabular}

\section{Critical Areas for Support}

Action required by other clusters (if yes, please check $\checkmark$ the box (es) below.)

\begin{tabular}{|c|c|c|c|c|c|c|c|c|c|c|c|c|c|c|}
\hline$\square$ & Health & $\diamond$ & $\begin{array}{l}\text { Communicable } \\
\text { Diseases }\end{array}$ & $\diamond$ & $\begin{array}{l}\text { Child } \\
\text { Health }\end{array}$ & $\diamond$ & $\begin{array}{l}\text { Sexual\& } \\
\text { Reproductive Health }\end{array}$ & $\diamond$ & MHPSS* & $\diamond$ & $\begin{array}{l}\text { Non-communicable } \\
\text { Diseases }\end{array}$ & $\diamond$ & $\begin{array}{l}\text { Other health issue } \\
\text { ( }\end{array}$ & ) \\
\hline$\square$ & WASH $^{\star *}$ & $\square$ & Food Security & $\square$ & Nutrition & $\square$ & Shelter & $\square$ & Other ( & & & & & \\
\hline
\end{tabular}

*MHPSS: Mental Health and Psychological Support, **WASH: Water, Sanitation and Hygiene

4. Situation of the Site / Shelter

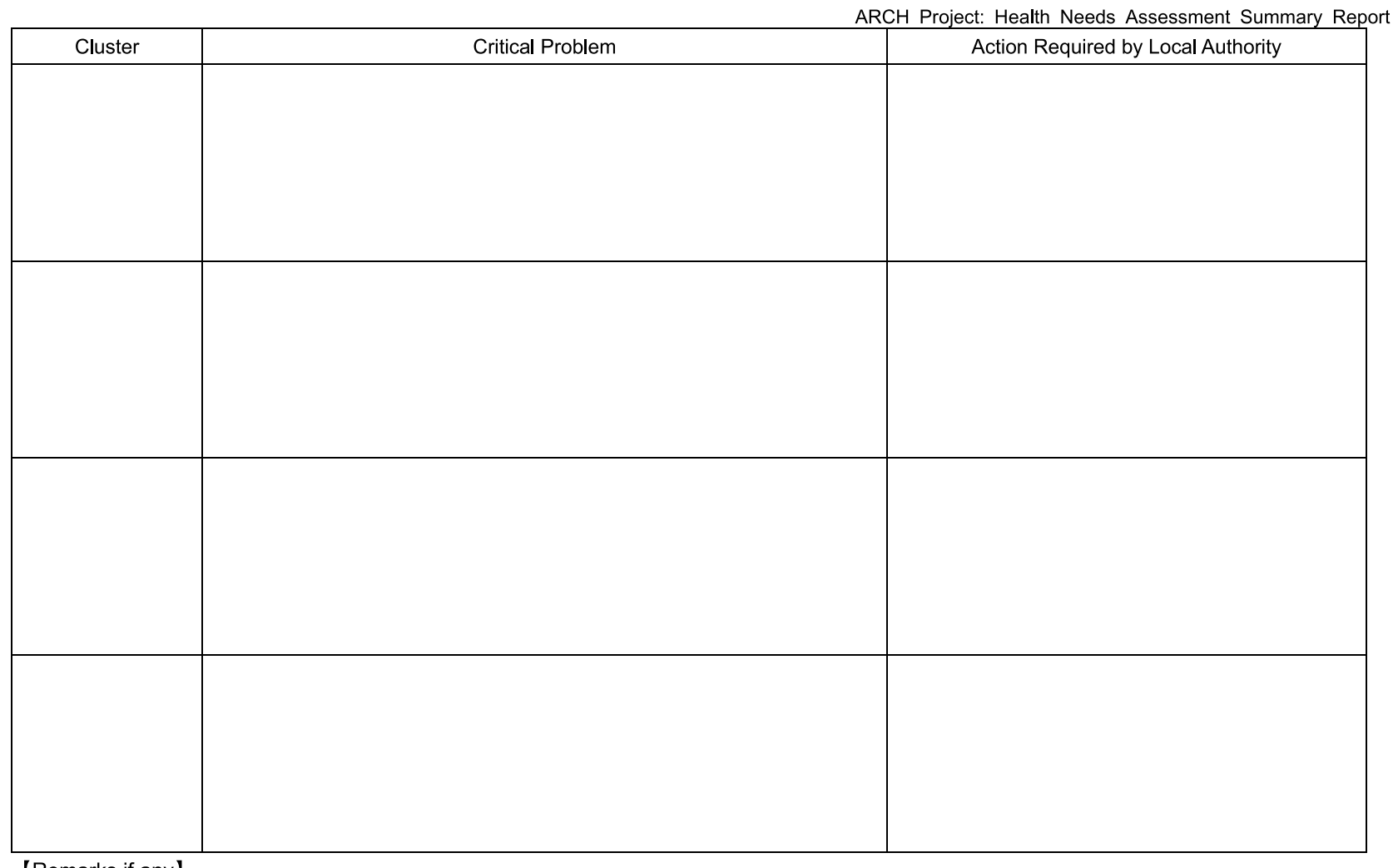

【Remarks if any】

Figure 3. Health Needs Assessment (HNA) Summary Report.

Note: This form is available in a Word document. https://docs.google.com/document/d/1RcSdhqnXfYbq91rgZe5Z7r HauQSiq9wa/edit?usp=sharing\&ouid=103468978621981742764\&rtpof=true\&sd=true. 


\begin{tabular}{|c|c|c|c|c|}
\hline \multirow[b]{2}{*}{ Recommendation } & \multirow[b]{2}{*}{ Specific Activities } & \multicolumn{3}{|c|}{ (Expected) Output/Project Phases } \\
\hline & & \begin{tabular}{|l|} 
Extension \\
July 2019- March 2021
\end{tabular} & \begin{tabular}{|l|} 
Re- Extension \\
April- December 2021
\end{tabular} & \begin{tabular}{|l|} 
ARCH2 \\
January 2022-
\end{tabular} \\
\hline $\begin{array}{l}\text { National SOP for receiving } \\
\text { I-EMT }\end{array}$ & & $\mathrm{N} / \mathrm{A}$ & $\mathrm{N} / \mathrm{A}$ & $\begin{array}{l}\text { AMS receive advice/ } \\
\text { support through Peer } \\
\text { Review on Necessary } \\
\text { National SOP }\end{array}$ \\
\hline \multirow[t]{3}{*}{ Training } & $\begin{array}{l}\text { Basic Disaster Health } \\
\text { Management (BDHM) } \\
\text { Course }\end{array}$ & \multirow{2}{*}{\multicolumn{2}{|c|}{ Standard Curricula are developed }} & \multirow{2}{*}{$\begin{array}{l}\text { Training courses are } \\
\text { implemented } \\
\text { Participants' DB is } \\
\text { developed }\end{array}$} \\
\hline & $\begin{array}{l}\text { In-country Coordination } \\
\text { Course }\end{array}$ & & & \\
\hline & $\begin{array}{l}\text { I-EMT (Advance/ToT) } \\
\text { Course } \\
\end{array}$ & $\mathrm{N} / \mathrm{A}$ & $\mathrm{N} / \mathrm{A}$ & $\begin{array}{l}\text { Curriculum is developed/ } \\
\text { Course is implemented }\end{array}$ \\
\hline \multirow[t]{3}{*}{ Other Specific Issues } & Preposition of EMT items & $\mathrm{N} / \mathrm{A}$ & $\mathrm{N} / \mathrm{A}$ & $\begin{array}{l}\text { Feasibility Study/ } \\
\text { Development of National } \\
\text { SOP }\end{array}$ \\
\hline & \multirow{2}{*}{$\begin{array}{l}\text { Guidance Document for } \\
\text { EMT SOP }\end{array}$} & \multicolumn{2}{|c|}{ Guidance Document (Waste Management) is developed } & \multirow{2}{*}{$\begin{array}{l}\text { Guidance Document for } \\
\text { WASH management is } \\
\text { developed }\end{array}$} \\
\hline & & \multicolumn{2}{|c|}{$\begin{array}{l}\text { Guidance Document (Medical accident/malpractice) is } \\
\text { developed }\end{array}$} & \\
\hline
\end{tabular}

Table 1. Recommendations of ACM

form is an essential factor in strengthening regional collaboration for disaster response.

The next step will be to provide more opportunities for EMTs in AMS and to learn in detail about using these forms. This is due to the fact that primary role of EMTs is considered to provide medical care and it may not be familiar with the assessment. But real-time HNA by the standardized form is critical to decide the priorities of relief operations. It is becoming more realistic to consider the integration of standardized HNA with their assessment and information systems in each county.

In summary, the ARCH Project successfully developed a rapid HNA tool in sudden-onset disasters (SOD) and emergencies, consisting of assessment and summary forms. EMTs and PHEOC would use these forms in ASEAN DHM. The use of a unified form would strengthen regional cooperation in the event of SOD.

\section{Collective Measures for Rapid, Effective and Quality EMT Operations in ASEAN}

POA stipulates that all AMS will have an I-EMT that is compliant to either ASEAN or WHO EMT minimum standards, and establish EMTCC in the event of SOD or other emergencies to effectively coordinate incoming EMT operations. ${ }^{6}$

All AMS have developed some form of EMTs (AMS EMTs), many of which have already been deployed internationally. However, according to the questionnaire survey conducted by the ARCH Project in 2018, many AMS indicated that it will be difficult to meet the WHO minimum requirements set out by the $\mathrm{WHO}$ EMT initiative in the specific areas which includes response to medical accidents, waste management, and logistics. ${ }^{9}$ To address these challenges, development of collective measures for EMT in ASEAN (hereinafter referred to the ASEAN Collective Measures or ACM in this article) was proposed to support AMS in their efforts to meet the $\mathrm{WHO}$ minimum requirements, and thereby realize rapid, effective, and quality emergency medical assistance. The ACM recommendations were summarized in Table 1.

The ARCH Project has formed a sub working group (SWG) for the ACM, consisting of representatives of five AMS, namely Indonesia, Myanmar, Philippines, Thailand, and Viet Nam. All of the mentioned countries have been severely affected by the major disasters in the past and have hosted or are planning to host ARCH Project's RCD together with Japan, ASEAN Secretariat, and the AHA Centre for the objective to analyze the situation, collect relevant information, and discuss possible solutions.

ASEAN has a number of advantages in organizing regional assistance, including EMT deployment, such as existing networks, systems, and agreements, as well as geographic proximity, cultural, religious, and linguistic similarities among neighboring countries. The ACM will be effective in leveraging these advantages and the on-going work to draft ACM recommendations has taken into consideration the ASEAN Mutual Recognition Arrangement (MRA). The MRA enables qualifications of medical professionals, recognized by the authorities in their home country, to be mutually recognized by other AMS. The arrangement has been developed under an initiative towards the realization of the ASEAN Economic Community. Furthermore, the Disaster Emergency Logistic System for ASEAN (DELSA) under which three warehouses with stockpile of relief items are operational in Malaysia, Philippines, and Thailand under the management of the AHA Centre. ${ }^{12-14}$

ACM recommendations to support strengthening AMS EMTs includes the development of guidance documents for waste management and response to medical accidents. It is also proposed to implement peer review by other AMS in addition to the curriculum design or implementation of relevant training such as "Basic Disaster Health Management (BDHM) 


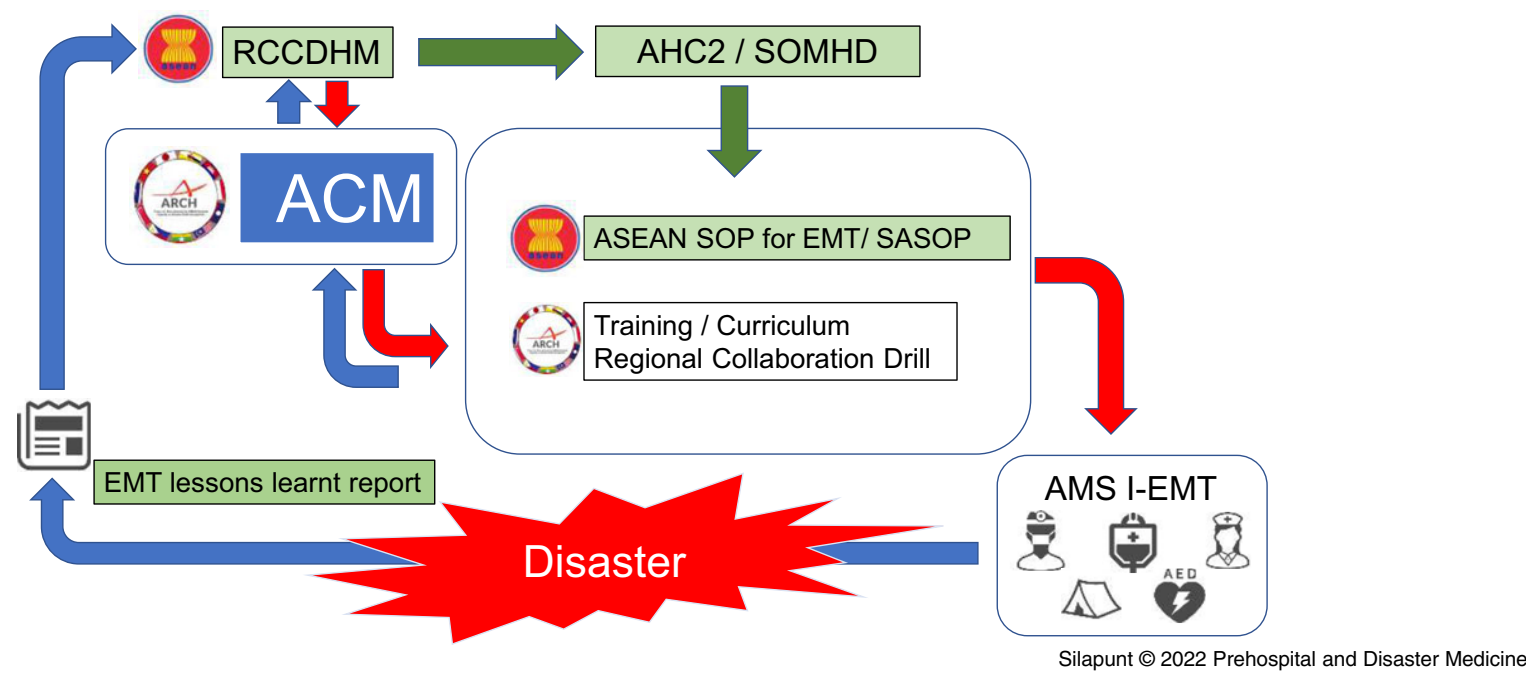

Figure 4. Future Status of ACM.

Course" and "Advanced Course for I-EMT" in the next phase of the ARCH Project.

In the course of discussions of the SWG for ACM, it was suggested that in order to realize rapid, effective, and quality EMT operation, it is not enough to support AMS to develop, maintain, and deploy EMTs in accordance with the WHO minimum standard, but rather it is crucial to strengthen EMT coordination capacity such as EMTCC management of AMS affected by SOD or other emergencies.

Based on the concept, it was proposed to organize training such as "In-country Coordination Course" for personnel who will be involved in the coordination of incoming EMTs or EMTCC, and for establishment of a human resource pool system registered by the course participants.

Development of a database for five AMS, namely, Indonesia, Myanmar, Philippines, Thailand, and Viet Nam, all of which are considered disaster-prone, is underway with a set of information including national procedures and necessary documents for customs, immigration, and quarantine. The database also contains the requirements for authorization for practice to foreign medical practitioners by the Ministry of Health or Ministry of Public Health of the disaster-affected AMS, and shall collect and clarify these requirements for I-EMT mobilization, operation, and entry into/exit from the country. The database is proposed to be regularly reviewed by the concerned AMS itself through ARCH Project activities such as the preparation process of the RCD in order to keep them updated.

Preposition of EMT medicine and equipment in the disasterprone country as a stockpile is also proposed to address challenges related to international transport.

The recommendations of the SWG for ACM will be submitted to the ASEAN RCCDHM through PWG1, and further may be elevated to the higher-level ASEAN Health Sector bodies, as appropriate.

Through the existing mechanism, it is expected that the efforts of the ACM will continue in the ARCH 2 Project as a problemsolving mechanism to address challenges raised through hosting and/or participating in the RCD, and through the EMT lessons learned report that was developed to extract challenges in receiving and coordinating international assistance after occurrence of actual disasters and thereby contributing to the strengthening the DHM framework in ASEAN (Figure 4).

\section{Conclusion}

The contribution of the ARCH Project to strengthen the ASEAN regional capacity in DHM has enhanced the regional coordination platform, with a formalization of RCCDHM as ASEAN's official regional mechanism, and of the on-going integration process of the SOP for EMT coordination into the ASEAN SASOP. The ARCH Project has a mechanism of transforming actual operations into SOPs and tools endorsed by higher health-related ASEAN bodies that also fulfill the WHO standards. The ARCH Project is also a continuous testing field to improve the DHM as one of the top priorities of ASEAN Post-2015 Health Development Agenda (APHDA).

\section{Author Contribution}

This manuscript was conceptualized and contributed by following authors: Ferdinal Fernando and Jim Catampongan (ASEAN aspects), Phumin Silapunt (RCC-DHM), Parinya Tianwibool (ASEAN SOP for EMT), Kanin Keeratipongpaiboon, and Yosuke Takada (Regional tools), Taro Kita, and Shuichi Ikeda (ACM). All authors have read through the final manuscript and agreed for publication.

\footnotetext{
References

1. ASEAN. The ASEAN Agreement on Disaster Management and Emergency Response (AADMER). http://agreement.asean.org/media/download/20190702042042.pdf. Published 2010. Accessed September 6, 2021.

2. ASEAN. ASEAN Post-2015 Health Development Agenda (2016-2020). https:// asean.org. Accessed September 6, 2021.

3. ASEAN. ASEAN Leaders' Declaration on Disaster Health Management. https:// asean.org/wp-content/uploads/2017/11/4.-ADOPTION_2017_ALD-on-DHM_ Endorsed-13th-AHMM.pdf. Published 2017. Accessed September 6, 2021.
}
4. ASEAN. ASEAN Declaration on One ASEAN, One Response: ASEAN Responding to Disasters as One in the Region and Outside the Region. https:// asean.org. Accessed September 6, 2021.
5. ASEAN. Joint Statement 12th ASEAN Health Ministers Meeting. https://asean.org/wp- content/uploads/images/2015/January/asean_health_minister_meeting/12th_AHMM_ Joint\%20Statement_Final.pdf. Published 2014. Accessed September 6, 2021.
6. ASEAN. Plan of Action to implement the ASEAN Leaders' Declaration on Disaster Health Management (2019-2025). https://asean.org. Accessed September 6, 2021.


7. The ASEAN Coordinating Centre for Humanitarian Assistance on disaster management. https://ahacentre.org/. Accessed September 6, 2021.

8. ASEAN. Standard Operating Procedure for Regional Standby Arrangements and Coordination of Joint Disaster Relief and Emergency Response Operations (SASOP). https://asean.org/wp-content/uploads/2018/02/59.-December-2017SASOP-6th-Reprint.pdf. Published 2017. Accessed September 6, 2021.

9. World Health Organization. Emergency Medical Teams: World Health Organization EMT Initiative. https://www.who.int/hac/techguidance/preparedness/emt-infonov2016.pdf. Published 2016. Accessed September 6, 2021.

10. JICA. The Survey on the Current Situation of Disaster/Emergency Medicine System in the ASEAN Region: Final Report. https://openjicareport.jica.go.jp/pdf/12237384 pdf. Published 2015. Accessed September 6, 2021.
11. Inter-Agency Standing Committee. Multi-Sector Initial Rapid Assessment (MIRA). https://interagencystandingcommittee.org/system/files/mira_manual_2015.pdf. Published 2015. Accessed September 6, 2021.

12. ASEAN Mutual Recognition Arrangements. ASEAN. http://investasean. asean.org/index.php/page/view/asean-free-trade-area-agreements/view/757/ newsid/868/asean-mutual-recognition-arrangements.html. Accessed May 13, 2021.

13. Disaster Emergency Logistics System for ASEAN (DELSA). ASEAN-Thailand Secretariat. https://www.asean2019.go.th/en/infographic/disaster-emergency-logisticssystem-for-asean-delsa/. Accessed May 13, 2021.

14. Resource management. AHA Centre. https://ahacentre.org/resource-management1/. Accessed May 13, 2021. 